\title{
Social and ethical issues in management accounting and control: an editorial
}

\author{
Jan Endrikat ${ }^{1}$. Frank Hartmann ${ }^{2}$. \\ Philipp Schreck ${ }^{3}$
}

Published online: 13 October 2017

(C) Springer-Verlag GmbH Germany 2017

Social and ethical issues currently receive considerable attention in academic research and professional practice in management accounting. One reason for this development is that companies face increasing pressures to address actively concerns with regard to the social and environmental impacts of their business activities. As a result, assuming responsibility for such impacts has become strategically important (e.g., Khan et al. 2016; Maas et al. 2016). At the same time, corporate scandals and instances of ethical misconduct, such as the Volkswagen Emissions Scandal, the Toshiba Accounting Scandal and the Libor Scandal, undermine public confidence in companies. In response to pressure to conduct their business in ways that meet the requirements of sustainable development, companies are gradually integrating sustainability-related issues into their measurement and control systems.

There is another reason for the rising prominence of social and environmental issues and that is rooted in the domain of management accounting itself. The function of management accounting is to provide information that facilitates and influences decision-making in companies. This function potentially involves a wide range of social and ethical issues, including honesty in managerial reporting (Brown et al. 2009), standards of integrity and ethical conduct (Kaptein and Avelino 2005), responsible supply chain management (Seuring and Müller 2008), and the dysfunctional effects of incentive systems (Hartmann and Schreck 2016).

In the field of management accounting and control, as in other management disciplines, such as strategic management, human resource management and organisational

\footnotetext{
Jan Endrikat

jan.endrikat@tu-dresden.de

1 Technische Universität Dresden, Dresden, Germany

2 Erasmus University Rotterdam, Rotterdam, The Netherlands

3 Martin-Luther-Universität Halle-Wittenberg, Halle, Germany
} 
behaviour, research on social and ethical issues has a long tradition. At the latest with the establishment of Accounting, Organizations and Society in 1976 and Anthony Hopwood's encouragement for research on the social role of accounting and social accounting (O'Dwyer and Unerman 2016), social and ethical issues have become important topics in management accounting research.

Management accounting and control play a pivotal role in the ability of companies to deal with social issues and exhibit corporate ethical behaviour. Management accounting has been defined as "an organisation's development of both non-monetary and monetary information to support both routine and strategic decision-making by internal managers" (International Federation of Accountants 2005, 16). The broader concept of management control refers to the "systems, rules, practices, values and other activities management put in place in order to direct employee behaviour" (Malmi and Brown 2008, 290). Understood in this way, management accounting and control constitute the basis for strategy implementation (Simons 1991), facilitate planning and organisational decision-making (Sprinkle 2003), and ensure that individuals and groups contribute with their decisions and actions to the achievement of organisational goals (Flamholtz et al. 1985). Given the importance of social and ethical issues in modern organizations, it is evident that research on management accounting and control needs to be concerned with social and ethical issues.

This special issue seeks to provide a snapshot of research that is primarily concerned with social and ethical issues that touch on the spheres of management accounting and control. Although we are well aware of the interactions and potential trade-offs between economic, social and environmental issues in the context of sustainability (Hahn et al. 2010; Unerman and Chapman 2014), we decided to focus this special issue on social and ethical aspects. While economic issues have always been at the core of management accounting research and environmental issues started attracting considerable interest from accounting scholars from the late 1990s onwards, social and ethical aspects have remained on the margins of management accounting research (Gray 2002).

One area of management accounting research on social issues that is rather well established concerns the drivers and consequences of (voluntary) Corporate Social Responsibility (CSR) disclosure. The paper of Anne Michaels and Michael Grüning focuses on the latter aspect and provides an empirical examination of the relationships between CSR disclosure and information asymmetry and cost of capital.

The authors take as their starting point the observation that, contrary to the rather conclusive empirical evidence that the relationship between CSR disclosure and corporate financial performance is positive, prior studies on the effects of CSR disclosure on capital costs have yielded mixed results. To investigate this conflict, the authors used a sample of 498 German companies and employed an "Artificial Intelligence Measurement of Disclosure" (AIMD) and found that CSR disclosure is related with reduced information asymmetry and with lower cost of capital. Their finding supports the proposition that CSR information is relevant to stock market participants and can yield economic benefits in terms of cost reductions. The paper in general-and its focus on German companies in particular-is especially timely given the recent adoption of the EU Directive 2014/95/EU, which became incorporated into national German law in March 2017. The adoption of the law, which makes it mandatory for large, pub- 
licly traded companies to provide standardized and measurable information on their business practices' impacts on society and the environment, drew some criticism from certain economic interest groups; however, the paper of Anne Michaels and Michael Grüning shows that companies may reap economic benefits from CSR disclosure.

The second paper in this special issue, by Patrick Velte and Martin Stawinoga, also focuses on corporate disclosure. The authors provide a literature review on the topical subject of integrated reporting (IR). In essence, IR is a holistic form of reporting a company's value creation in that it takes into account both financial and non-financial (such as human, social, and intellectual) resources. IR is based on the idea of using integrated thinking as "a means by which the different value streams associated with each of the capitals are combined to tell a relational performance story" (Oliver et al. 2016, 229). Because of that, IR is considered to enable corporations to align profit maximization with social and environmental objectives more effectively (de Villiers and Sharma 2017). In their literature review, Patrick Velte and Martin Stawinoga summarise 44 empirical studies, using different methodological approaches (e.g., experiments, surveys, case studies), and discuss a multi-level research agenda from which they derive recommendations for future research, based on the limitations of the studies they review.

The paper of Tobias Johansson and Gabriella Wennblom focuses on an aspect, that the authors describe as "perhaps the most embedded and common social structure of society and organisations", namely gender. Supervisor-subordinate dyads are central to various management control settings such as performance evaluation, budget control and target setting. The authors argue that although research in other disciplines has shown that gender may significantly affect perceptions and behaviour, most studies of management accounting and control that explore psychological or behavioural concepts (such as fairness perception or trust) neglect the aspect of gender. Using a $2 \times 2$ vignette experiment, Tobias Johansson and Gabriella Wennblom found that gender affects perceptions of fairness in the case of tight control as well as trust in management. Specifically, the authors found that male subordinates perceive control evaluation as fairer and male subordinates under a female supervisor trust management more than males under a male supervisor or females under a female supervisor. In sum, this paper demonstrates that research should take into account the impact of gender and gender roles in management control settings.

The final paper in this special issue is by Frederik Plewnia and Edeltraud Günther. In their study, the authors provide a meta-analytic examination of the relationship between corporate philanthropy (CP), i.e., voluntary corporate giving to charitable organisations, and corporate financial performance (CFP). From a theoretical point of view, $\mathrm{CP}$ may be positively related to CFP because $\mathrm{CP}$ can enhance external corporate reputation and because $\mathrm{CP}$, as part of an organization's values and belief system, can strengthen employee identification, motivation and commitment. The authors quantitatively synthesise statistical information from 45 empirical studies and find that the relationship between CP and CFP is, on the whole, significant and positive. Furthermore, the authors found that this result holds after examining only time-lagged correlational estimates, which suggests that CP has a causal impact on CFP. The subgroup analysis they performed shows that this positive relationship is robust across different study designs (e.g., differing in the sampling criteria or construct opera- 
tionalisations). In sum, this study suggests that CP can become usefully integrated in a company's beliefs and value system and help support community welfare and foster financial performance at the same time.

In summary, we believe that the papers in this special issue convincingly demonstrate both the broad spectrum of interesting and important topics and the methodological breadth of research in management accounting and control that focuses on social and ethical issues. In view of the recent global disruptions and the complex challenges with regard to the economic, social and environmental spheres, management accounting and control research that actively addresses the societal impact of business and takes into account social and ethical issues is of utmost importance. We hope that this special issue contributes to the further development of this research.

Following a starting tradition of JoMaC, the editors of JoMaC would like to honour the enduring support by our reviewers, their fruitful and motivating comments to further develop the papers of our authors, and, nevertheless, their investment in time and effort often in addition to full workloads at their home bases with the 2016 Best Reviewer Awards. Out of a long list of outstanding reviewers the editors finally decided to honour the following scholars:

Best reviewer award 2016: $\quad$ David Bedford, University of Technology, Sydney, Australia

Distinguished Reviewers 2016: Ricardo Malagueno, University of East Anglia, United Kingdom

Thorsten Knauer, Ruhr University of Bochum, Germany

Barbara Weißenberger, Heinrich-Heine University, Düsseldorf, Germany

Eric Strauss, University of Witten/Herdecke, Germany

Takehisa Kajiwara, Kobe University, Japan

The editors of JoMaC would like to announce one special issue, which is planned for 2019 and thus allows enough time for planning, preparation and inspiration:

Digitalization of Management Accounting and Control, guest-edited by Klaus Möller, University of St. Gallen, Switzerland, Utz Schäffer, WHU - Otto Beisheim School of Management, Vallendar, Germany, and Frank Verbeeten, Utrecht University and Vrije Universiteit Amsterdam, The Netherlands

\section{Deadline: January 31, 2019}

For further information see the web site of JoMaC.

Dresden/Rotterdam/Halle-Wittenberg, September 2017.

Jan Endrikat, Frank Hartmann, Philipp Schreck 


\section{References}

Brown, J. L., Evans, J. H, I. I. I., \& Moser, D. V. (2009). Agency theory and participative budgeting experiments. Journal of Management Accounting Research, 21(1), 317-345.

de Villiers, C., \& Sharma, U. (2017). A critical reflection on the future of financial, intellectual capital, sustainability and integrated reporting. Critical Perspectives on Accounting. doi:10.1016/j.cpa.2017. 05.003 .

Flamholtz, E. G., Das, T. K., \& Tsui, A. S. (1985). Toward an integrative framework of organizational control. Accounting, Organizations and Society, 10(1), 35-50.

Gray, R. (2002). The social accounting project and accounting, organizations and society privileging engagement, imaginings, new accountings and pragmatism over critique. Accounting, Organizations and Society, 27(7), 687-708.

Hahn, T., Figge, F., Pinkse, J., \& Preuss, L. (2010). Trade-offs in corporate sustainability: You can't have your cake and eat it. Business Strategy and the Environment, 19(4), 217-229.

Hartmann, F., \& Schreck, P. (2016). Rankings. Performance and sabotage: The moderating effects of target setting. European Accounting Review. doi:10.1080/09638180.2016.1244015.

International Federation of Accountants. (2005). Environmental management accounting. New York: IFAC.

Johansson, T., \& Wennblom, G. (2017). In female supervisors male subordinates trust!? An experiment on supervisor and subordinate gender and the perceptions of tight control. Journal of Management Control, 11(2). doi:10.1007/s00187-017-0248-7.

Kaptein, M., \& Avelino, S. (2005). Measuring corporate integrity: A survey-based approach. Corporate Governance: The International Journal of Business in Society, 5(1), 45-54.

Khan, M., Serafeim, G., \& Yoon, A. (2016). Corporate sustainability: First evidence on materiality. The Accounting Review, 91(6), 1697-1724.

Maas, K., Schaltegger, S., \& Crutzen, N. (2016). Integrating corporate sustainability assessment, management accounting, control, and reporting. Journal of Cleaner Production, 136(Part A), 237-248.

Malmi, T., \& Brown, D. A. (2008). Management control systems as a package-Opportunities, challenges and research directions. Management Accounting Research, 19(4), 287-300.

Michaels, A., \& Grüning, M. (2017). Relationship of corporate social responsibility disclosure on information asymmetry and the cost of capital. Journal of Management Control, 11(2). doi:10.1007/s00187017-0251-z.

O’Dwyer, B., \& Unerman, J. (2016). Fostering rigour in accounting for social sustainability. Accounting, Organizations and Society, 49, 32-40.

Oliver, J., Vety, G., \& Brooks, A. (2016). Conceptualising integrated thinking in practice. Managerial Auditing Journal, 31(2), 228-248.

Plewnia, F., \& Günther, E. (2017). The benefits of doing good: A meta-analysis of corporate philanthropy business outcomes and its implications for management control. Journal of Management Control, 11(2). doi:10.1007/s00187-017-0252-y.

Seuring, S., \& Müller, M. (2008). From a literature review to a conceptual framework for sustainable supply chain management. Journal of Cleaner Production, 16(15), 1699-1710.

Simons, R. (1991). Strategic orientation and top management attention to control systems. Strategic Management Journal, 12(1), 49-62.

Sprinkle, G. B. (2003). Perspectives on experimental research in managerial accounting. Accounting, Organizations and Society, 28(2), 287-318.

Unerman, J., \& Chapman, C. (2014). Academic contributions to enhancing accounting for sustainable development. Accounting, Organizations and Society, 39(6), 385-394.

Velte, P., \& Stawinoga, M. (2017). Integrated reporting: The current state of empirical research, limitations and future research implications. Journal of Management Control, 11(2). doi:10.1007/s00187-0160235-4. 